\title{
Massive Online Obsessive Compulsion: What are They Saying Out There about the Latest Phenomenon in Higher Education?
}

Vera L B Dolan

University of Toronto, Canada

\section{Abstract}

This article is a review of ideas, comments, and inquiries about massive open online courses (MOOCs) gathered from a wide variety of online journal and magazine articles, and web blogs. As a seasoned "traditional" online educator, as well as a student participant in several MOOCs, I also take the opportunity to share my personal insight from my own learning experiences, with the goal of illustrating some of the concerns unearthed in my research. One serious issue regarding MOOCs is that some learners can feel isolated and/or neglected, particularly when they perceive that other course participants and/or the professor are ignoring their contributions. Our era has witnessed "the McDonaldization of Education" (Lane \& Kinser, 2012), in which one size fits all and information is delivered to student "customers" via systematically managed "factories" whose overseers frown upon any supposed waste of valuable resources or human effort. In the mass-appeal environment of a MOOC, it is quite possible that a student will receive no customized feedback from nominal experts in the field. Lack of meaningful interaction is likely a key factor driving high attrition numbers in the online education environment - numbers that are apparently even higher in the case of MOOCs.

The ideas presented herein also formed part of a webinar that I created for Pennsylvania State University in March 2013.

Keywords: MOOCs; online education; open universities; peer grading; attrition; course credit; McDonaldization 


\section{In the Beginning...}

Not long ago I had the opportunity to present a webinar for Pennsylvania State University discussing what we know so far about massive open online courses (MOOCs). Although only a few months have passed since my presentation, it would be more accurate to say "what we knew about MOOCs", because every day we seem to get another update on how this most recent mode of delivering higher education has further evolved.

We seem to be compulsively obsessed with MOOCs. We wake up every morning realizing that someone somewhere, myself included, is writing an article, an essay, a blog, you name it, in an effort to dissect what these courses represent and their impact on global higher education. We have even reached the state where MOOCs are coined with lowercase prefixes: cMOOCs, connecting people and relying on person-to-person exchanges; xMOOCs, predominantly computer graded with low human interaction; and now oMOOCs, where the "o" stands for original (Bell, 2013). It seems that, with so many current variations in how these courses are used by educational institutions, original refers back to what Canadian educators Stephen Downes and George Siemens had in mind when they launched the first MOOC in 2008 - which was also the first of a series of MOOCs I have participated in as a student. Entitled Connectivism and Collective Knowledge (CCK08), it was meant to provide access to the masses and to "people who cannot afford to pay the cost to travel to and attend [...] small in-person events" (Bell, 2013, ๆ 2). Moreover, "original MOOCs (oMOOCs) were free, or at least extremely affordable, fully online, well-crafted, and contained a lot of interesting pedagogy and institutional design. The target demographic was the underserved, both nationally and internationally" ( $(\mathbf{5}$ ). Indeed, my impression was that the CCK08 course had participants from all corners of the planet, with an enormous variety of social, cultural, and professional backgrounds.

\section{Rapid Paradigmatic Changes}

Now that a few years have passed since CCK08, we see a wide range of deviations from the initial intent, based on what the constantly growing MOOC-related literature has brought to light so far. As is the case with any innovation, making sense of MOOCs has become a never-ending quest for many of us - an attempt to nail down how they affect, both positively and negatively, the lives of all stakeholders. This is why so much has been written about the subject and why the controversy surrounding MOOCs only seems to grow.

There is no shortage of supporters for this new paradigm in higher education, despite the fact that students in MOOCs must embrace what seems to be a chaotic learning environment in which the apparent virtues of openness and connectedness also bring a high degree of complexity and the need for greater self-organization (deWaard, Abajian, 
Gallaher, Hogue, Keskin, Koutropoulos, \& Rodriguez, 2011). As Vaidhyanathan (2012) puts it,

The strangest thing about this MOOC obsession is the idea that something that very wealthy private institutions offer for free, at a loss, as a service to humanity, must somehow represent the magic numbers in the higher-education lottery. It's new, it's "innovative," and it's big, the thinking goes. So it must be the answer ( $₫ 5)$.

\section{The Pros and Cons}

Thomas Friedman, a columnist from The New York Times, is enthusiastic about MOOCs and has raised eyebrows - including mine - for painting what some critics perceive as a naïve and one-dimensional picture of their wonders. From his perspective, all MOOCs seem to have an "o" prefix because they offer the potential to revolutionize higher education, finally allowing the global population to gain free access to top-quality education and escape poverty (Friedman, 2013). André Dua (2013), a McKinsey \& Company director, asserts that MOOCs, if delivered properly, "[promise] students faster, more consistent engagement with high-quality content, as well as measurable results" ( $₫ 1$ ). Although both writers find supporters among leaders of prestigious institutions - for instance, H. K. Bottomly, president of Wellesley College (Letter to the editor, The New York Times, 2013) - there are numerous dissenting opinions. DePaul University's Beth Rubin notes that Friedman does not mention some key limitations of MOOCs, and cites low completion rates as just one example. Rubin goes on to say:

There is limited formative feedback to help students develop critical thinking and writing skills; assessment is typically either computer-graded or "crowd sourced." [...] Most students do not get known as individuals, so there is little sense of social presence. [...] Generally only the driven, self-motivated and organized students who already have strong basic skills are likely to succeed (Letter to the editor, The New York Times, ๆ 5).

In her short note, Rubin summarizes the critical issues that have been debated ad nauseam: attrition rates; lack of meaningful interaction between faculty and course participants; and the pitfalls of peer grading. And then there is an even more crucial issue: Should students be given credit for these courses and, if so, under what circumstances? The fact is that, "over the last year, massive open online courses, or MOOCs, have quickly traversed the cultural cycle of hype, saturation, backlash, and 
backlash-to-the-backlash" (Carey, 2012, I 6). The opinions just keep coming, but verdicts seem to be moving further out of reach.

For the longest time I was purely a MOOC detractor, and, although I have finally caught a glimpse of the positive aspects of this type of course, I could not help but respond to Friedman's column with a high dose of cynicism. In fact, in one of my infrequent blog posts, I commented:

The hype surrounding [MOOCs] these days seems to be growing by the minute; apparently, anyone can create a MOOC, anyone can teach a MOOC, anyone can learn from a MOOC. Even better, anyone can learn from a MOOC, even if there are $500,1,000$ or 100,000 people providing their input, alternating themselves in the role of educators. Welcome to the deMOOCracy era! Now everyone can have a shot at teaching, everyone can learn, everyone can collaborate. And for my fellow dinosaurs who remember the 1973 film Lost Horizon, let's all take a MOOC while singing "Living Together, Growing Together" (2012, ๆ 6).

\section{Learning - A Matter of Semantics?}

This notion that MOOCs can elevate humanity to a new reality in which everyone benefits - learning from the best post-secondary educators and gaining a chance at a more fulfilling life - is seductive. However, it originates in a utopian desire and is unlikely ever to happen. For starters, we must define "learning". If by learning we mean having the opportunity to view a recorded lecture by a renowned professor from a topranked university, and to be referred to additional materials related to the topic presented, then yes, one could say that everyone with an Internet connection anywhere in the world can learn. But the fact is that this is the kind of learning that can only happen in Shangri-La, to return to my Lost Horizon reference - and those who remember the film will also recall that once you left the valley, things did not go well.

The problem with the MOOC learning experience is that the mere exposure to information does not lead to the assimilation of knowledge and personal growth. In my own experience as both student and teacher - mentored as a novice, incidentally, by the aforementioned Beth Rubin of DePaul University - I find that learning requires regular back-and-forth exchanges, with validation and constructive criticism of one's ideas. My years of teaching have led me to fully appreciate what Rubin stressed when she first guided me in delivering courses online: If I do not have opportunities to bounce some of my ideas off others in the class and gain the feedback I am hoping to receive, the odds are high that I'll realize that the information is not etched in my brain - it does not 
come as second nature when put to the test in the real world. Indeed, all I have really learned after having taken several MOOCs is that I become extremely frustrated when I seem to be talking to the virtual walls that contain them. I become deflated and I want to leave the environment in a hurry, because it does not inspire positive associations. In other words, lack of meaningful interaction has been detrimental to my desire to continue participating in a MOOC. My case definitely illustrates some of the research findings about MOOCs, in which feelings of social and intellectual disconnection negatively influence learners' motivation to carry on to the end of class.

As noted by Rubin (2013) - and also in The New York Times (2013) - student attrition rates have reached the $90 \%$ mark, even in small-scale online courses. Vaidhyanathan (2012) observes that these high attrition numbers seem to have been swept away by all the fanfare surrounding these courses and the congratulatory enthusiasm around enrolment numbers that reach into the thousands. However, the truth is that many course participants seem to lose momentum once they realize that there are no incentives for course participation (Chambelin \& Parish, 2011). When it is practically impossible for a professor to interact with thousands of students - even $1 \%$ of a MOOC student population could represent as many as 1,000 people (Mittell, 2013) - and when many learners still rely on teacher-student interaction to stay motivated and on track, it is not surprising that huge numbers of them give up, often in the first week of the course. No matter how sophisticated the technology used in a MOOC, for professors such as Timothy Burke of Swarthmore College, the essence of education still lies in the subtle interplay between students and teachers, which cannot be simulated by machines, regardless of refinements in programming (Carr, 2012). Nevertheless, Coursera co-founder Daphne Koller sees the need to clarify one point: No direct correlation can be established between lack of course completion and failure of the MOOC idea. In Koller's view, it all depends on each student's intent when enrolling in a course. Many only want to explore, perhaps exchange ideas with others and move on to something else without taking quizzes or completing assignments (Kolowich, 2013). But even when students intend to complete a course and participate in every activity, the use of peer grading - a practice adopted by Coursera professors who have to rely on course participants to assess each other's work - may become a source of discouragement and a strong reason to drop out. In this regard Lewin (2012) raises an important question: How can one be sure whether any MOOC participant is capable of matching the professor's grading standards?

\section{The Credit Controversy}

An even more troubling matter is the question of credit. Many colleges are likely to start accepting MOOC certificates as transfer credits - particularly when they see this concession as a significant tool for marketing, and consequentially higher enrolment numbers (Carey, 2012). But according to a survey conducted by the journal Chronicle of 
Higher Education, 72\% of faculty members who have taught MOOCs still don't think credits should be granted (Ferenstein, 2013). Nevertheless, the American Council on Education's College Credit Recommendation Service (ACE CREDIT) has already given its stamp of approval to five Coursera courses. ACE President Molly Corbett Broad believes in the endorsed validity of some courses, as long as professors thoroughly evaluate course content, pedagogy employed, and evidence of student engagement, among other elements, and conclude that these are on a par with equivalent courses taught by an accredited university (Young, 2012).

Aside from whether MOOCs are worthy of any credits, there is also the issue surrounding what accreditation might mean to traditional faculty members, particularly those who are not tenured. Parry (2013), in paraphrasing Richard Grusin, an English professor at UW-Milwaukee, suggests,

When colleges start to award credit for MOOCs serving thousands of students, the result could be a reduction in the need for faculty members to teach those courses. [...] Much of that reduction [...] would hit teaching assistants. Rather than teaching their own sections or classes, they may find themselves managing online discussions" ( $($ 8).

\section{The Implications}

Scepticism surrounding the benefits of MOOCs is far from negligible. Indeed, those who oppose the concept do so loudly. Gary W. Matkin, Dean of Continuing and Distance Education at the University of California, Irvine, warns that "everyone should be afraid of MOOCs, although there are some that should be more afraid than others" (Wallis, 2013, I 10). For many detractors, MOOCs epitomize "the McDonaldization of education" - they make it easy to obtain, inexpensive and insubstantial (Schmidt, 2013). And to extend the analogy: Fast food may taste good to many if not most of us, but no one could expect to live a long and healthy life relying solely on its poor nutritional value. Sooner or later, we'd need a radical and substantial change in our eating habits or otherwise we'd perish.

The University of California faculty union laments that professors "irrevocably grant the university the absolute right and permission to use their course content, name, image and likeness" (Rivard, 2013, ๆ 4), which has the potential to weaken faculty intellectual property rights and collective bargaining agreements. Furthermore, MOOCs, according to Gerry Canavan, assistant professor at Marquette University in Milwaukee, WI, boost the trend toward hiring adjuncts and devalue labour in the university environment. Canavan asserts that MOOCs embody a "labour model in search of a pedagogy" (Beware of MOOCs, ASQ Higher Education Brief, 2013, ๆ 7). 


\section{Where Are Faculty in All of This?}

When so much seems to be at stake for faculty, their views are of fundamental importance, although some claim that their voices have not been heard when it comes to the decision to embrace MOOCs (Azevedo, 2012). For Peter Struck, professor of classical studies at the University of Pennsylvania (Chronicle of Higher Education interview, 2012), the biggest concern is whether a faculty member can cultivate the engagement and dedication that students must put into their studies in order to gain value from the educational experience. Otherwise MOOCs can simply become a means to transfer data, which is not transformative and hence not a noteworthy form of education. As a veteran online instructor, I cannot fathom leading a class in which I do not have customized contact with each and every one of my students. And, as a student, I crave tailored feedback that will help me grow and fulfill my need for self-actualization. Therefore, it is in my nature to try to give my students what I believe they are looking for in order to have a positive course experience. So far no one has told me to stop providing customized treatment.

Some faculty, while not totally averse to the MOOC concept, remain cautious. However, the March 2013 Chronicle of Higher Education survey reveals that for half of respondents MOOCs, despite being time and energy consuming, can be as successful and as academically rigorous as the traditional versions of their courses. Additionally, many professors seem to feel that MOOCs should be incorporated "into the traditional system of credit and degrees" ( ( 9). I agree, provided that these courses are used as support tools in the traditional delivery of education. MOOCs can be strong allies in educating people who have a concurrent opportunity to experience meaningful and customized interactions with peers and faculty.

Faculty members who have embraced the MOOC reality, at least at first glance, have a variety of reasons for doing so. However, they seem to have two main sources of motivation: One, altruistic in nature, is the ability to reach a student population that otherwise might never have the opportunity to learn from the very best scholars. On the other hand, a great many faculty members seem to be teaching MOOCs for egocentric reasons: They do not want to be left behind by their peers; they hope to increase their visibility and perhaps gain tenure more quickly; they hope to sell more of their textbooks; they like the idea of reaching a larger audience (Kolowich, 2013); and some enjoy the celebrity status they've gained even among students abroad (Friedman, 2013).

\section{Are MOOCs Really Worth the Cost of Delivery?}

Despite the diversity of opinion, MOOC providers and their university partners seem to believe that they will ultimately see a payoff for the time and financial resources invested in the preparation and delivery of these courses. Given the undeniable high figures of enrolment in MOOCs, their proponents feel impelled to carry on, striving to 
find ways to begin making money. In fact, Coursera seems to have begun making some return on its investment - or rather, the investment of venture capital firms such as Kleiner Perkins Caufield \& Byers and New Enterprise Associates (Levy, 2012). Under Coursera's "Signature Track", for US\$50 students can pay to write proctored exams and receive a verified completion certificate (Rivard, 2013). This idea put US $\$ 220,000$ into the company's coffers in the first quarter of 2013. Coursera also receives a percentage of Amazon.com's sales when its course participants purchase textbooks suggested by a professor. Nevertheless, meaningful revenues have yet to be realized by MOOC providers, who have been working incessantly on ideas that might finally allow them to monetize the MOOC experience.

The opinion that MOOCs help build a university's brand is not unusual among some professors and administrators (Anderson, 2012). For the University of Virginia, for example, offering MOOCs might bring two kinds of return on investment. The first is more noble: the general public's opportunity to gain knowledge from a reputable university. The second form of return is more self-interested (Vaidhyanathan, 2012): the strengthening of the university's name, which should attract more students. Friedman (2013) presents an example of this kind of "branding" at work: A 15-year-old Mongolian student who took a MOOC with the Massachusetts Institute of Technology and the University of California, Berkeley was encouraged to apply to both institutions after receiving a perfect score on his final exam.

\section{Some Final, Fundamental Questions}

The good news is that with the advent of open education, universities and colleges are revisiting their missions and focusing significantly more attention on providing better quality of teaching (Daniel, 2012). As Chamberlin and Parish (2011) have suggested, the sense of connectedness in the online experience encourages learners to expand their knowledge base and elaborate on their interpretations. At the very least, MOOCs can definitely be complementary to what colleges do (Wallis, 2013). But what is even more certain is that there is still a myriad of unanswered questions, at least for the time being. Udacity's founder, Sebastian Thrun, wonders whether MOOC classes have the power to reach current university students and take away business from traditional institutions or if they in fact reach new students and add to the overall education market (Wallis, 2013). Other important questions to consider include:

- What is the value added by university campuses "when demand can be aggregated either by bringing students to campus or, much less expensively, by reaching and teaching students online virtually anywhere in the world" (Guile, 2013, ๆ 8).

- "Emerging technologies may allow us to educate the world more efficiently, [but...] can we educate people more effectively" (Head, 2013, ๆ 1)? 
- And finally, perhaps the most critical question of all: What are MOOCs for (Rivard, 2013)?

I'll end this paper with my own question: Why are we so compulsively obsessed with comparing apples to oranges? If we are so concerned with which medium delivers higher quality of education - MOOCs or traditional classes - then we must first look for ways to enhance all educational environments, regardless of their nature, and let students choose the route that best satisfies their personal needs. Why should the two environments be mutually exclusive? Let both traditional and massive online courses earn that "o" prefix, indicating that the intent that shaped them reflects the original plan - encouraging people to become decent and ethical citizens of the world, striving for a better and less unhappy society. 


\section{References}

Anderson, N. (2012, November 3). Elite education for the masses. The Washington Post. Retrieved from http:// articles.washingtonpost.com/2012-1103/local/35506250 1_coursera-free-online-courses-higher-education

Azevedo, A. (2012, September 26). In colleges' rush to try MOOC's, faculty are not always in the conversation. The Chronicle of Higher Education. Retrieved from http://chronicle.com/article/In-Colleges-Rush-to-Try/ 134692/

Bell, K. (2103, May 6). The hijacking of MOOCs. Inside Higher Ed. Retrieved from http:// www.insidehighered.com/views/2013/ 05/ 06/ essay-suggests-moocsare-losing-their-original-worthy-goals

Beware of MOOCs. (2013). ASQ Higher Education Brief, 6(2). Retrieved from http:// asq.org/ edu/2013/03/innovation/ beware-ofmoocs.pdf?WT.dcsvid=ODk0Mzg1MTAyNAS2\&WT.me id=EM119905

Bottomly, H. K. (2013, J anuary 28). Online courses and pitfalls. [Letter to the editor.] The New York Times. Retrieved from http:// www.nytimes.com/2013/01/29/opinion/online-courses-possibilitiesand-pitfalls.html

Carey, K. (2012, September 3). Into the future with MOOC's. The Chronicle of Higher Education. Retrieved from http:// chronicle.com/article/Into-the-Future-WithMOOCs/ 134080

Carr, N. (2012, September 27). The crisis in higher education. MIT Technology Review. Retrieved from http:// www.technologyreview.com/featuredstory/429376/thecrisis-in-higher-education/

Chamberlin, L., \& Parish, T. (2011, August). MOOCs: Massive open online courses or massive and often obtuse bourses? eLearn Magazine. Retrieved from http:// elearnmag.acm.org/ featured.cfm?aid=2016017

Daniel, J . (2012, September 25). [Web log message]. Making sense of MOOCs: Musings in a maze of myth, paradox and possibility. Retrieved from http://sirjohn.ca/ wordpress/wpcontent/ uploads/ 2012/ 08/ 120925MOOCspaper2.pdf

deWaard, I., Abajian, S., Gallagher, M. S., Hogue, R., Keskin, N., Koutropoulos, A., \& Rodriguez, O. C. (2011). Using mLearning and MOOCs to understand chaos, emergence, and complexity in education. International Review of Research in Open \& Distance Learning, 12(7), 94-115. 
Dua, A. (2013, may). College for all. Retrieved from http://www.mckinsey.com/insights/social sector/college for all

Ferenstein, G. (2013, March 22). Cited as Fereinstein ; please ensure correct spelling $72 \%$ of professors who teach online courses don't think their students deserve credit. Retrieved from http:// techcrunch.com/2013/03/22/72-of-professorswho-teach-online-courses-dont-think-their-students-deserve-credit/

Friedman, T. L. (2013, J anuary 26). Revolution hits the universities. The New York Times. Retrieved from http://www.nytimes.com/2013/01/27/opinion/sunday/friedman-revolutionhits-the-universities.html

Friedman, T. L. (2013, March 5). The professor's big stage. The New York Times. Retrieved from http:// www.nytimes.com/2013/03/06/opinion/friedman-theprofessors-big-stage.html? $\mathrm{r}=0$

Guile, B. (2013, March 12). The real winners of the coming revolution in higher education. Forbes. Retrieved from http:// www.forbes.com/ sites/forbesleadershipforum/2013/03/12/the-realwinners-of-the-coming-revolution-in-higher-education/

Head, K. (2013, J anuary 24). Here a MOOC, there a MOOC: But will it work for freshman composition? The Chronicle of Higher Education. Retrieved from http:// chronicle.com/blogs/ wiredcampus/ here-a-mooc-there-a-mooc-but-willit-work-for-freshman-composition/41883

Kolowich, S. (2013, J anuary 23). Universities try MOOCs in bid to lure successful students to online programs. The Chronicle of Higher Education. Retrieved from http:// chronicle.com/blogs/ wiredcampus/ universities-try-mooc2degreecourses-to-lure-successful-students-to-online-programs/41829

Kolowich, S. (2013, February 4). Georgia Tech and Coursera try to recover from MOOC stumble. The Chronicle of Higher Education. Retrieved from http://chronicle.com/blogs/ wiredcampus/ georgia-tech-and-coursera-try-torecover-from-mooc-stumble/ 42167

Kolowich, S. (2013, February 7). American Council on Education recommends 5 MOOCs for credit. The Chronicle of Higher Education. Retrieved from http:// chronicle.com/article/article-content/ 137155/

Kolowich, S. (2013, February 18). Professor leaves a MOOC in mid-course in dispute over teaching. The Chronicle of Higher Education. Retrieved from http:// chronicle.com/blogs/ wiredcampus/ professor-leaves-a-mooc-in-midcourse-in-dispute-over-teaching/ 42381 
Kolowich, S. (2013, February 21). How EdX plans to earn, and share, revenue from its free online courses. The Chronicle of Higher Education. Retrieved from http:// chronicle.com/article/How-EdX-Plans-to-Earn-and/ 137433/

Kolowich, S. (2013, February 21). Competing MOOC providers expand into new territory -and each other's. The Chronicle of Higher Education. Retrieved from http:// chronicle.com/blogs/ wiredcampus/competing-mooc-providers-expandinto-new-territory-and-each-others/42463

Kolowich, S. (2013, March 4). Online education may make top colleges more elite, speakers say. The Chronicle of Higher Education. Retrieved from http://chronicle.com/article/Online-Education-May-Make-Top/137687/

Kolowich, S. (2013, March 18). The minds behind the MOOCs. The Chronicle of Higher Education. Retrieved from http:// chronicle.com/article/The-ProfessorsBehind-the-MOOC/ 137905/\#id=overview

Kolowich, S. (2013, March 20). SUNY signals major push toward MOOCs and other educational models. The Chronicle of Higher Education. Retrieved from http://chronicle.com/blogs/ wiredcampus/suny-signals-major-push-towardmoocs-and-other-new-educational-models/43079

Lane, J ., \& Kinser, K. (2012, September 28). MOOC's and the McDonaldization of global higher education [blog]. Retrieved from http:// chronicle.com/blogs/ worldwise/ moocs-mass-education-and-themcdonaldization-of-higher-education/30536

Levy, A. (2012, April 18). Education startup Coursera raises \$16 million From Kleiner, NEA. Retrieved from http:// www.businessweek.com/news/2012-04$\underline{\text { 18/ education-startup-coursera-raises-16-million-from-kleiner-nea }}$

Lewin, T. (2012, J uly 17). Universities reshaping education on the Web. The Chronicle of Higher Education. Retrieved from http:/ / www.nytimes.com/ 2012/ 07/ 17/ education/ consortium-of-collegestakes-online-education-to-new-level.html?pagewanted=all

Mittell, J . (2013, March 4). Cited as Mittel ; please ensure correct spellingThe real digital change agent. The Chronicle of Higher Education. Retrieved from http:// chronicle.com/article/The-Real-Digital-Change-Agent/ 137589/

Parry, M. (2013, May 8). Scholars sound the alert from the "dark side" of tech innovation. The Chronicle of Higher Education. Retrieved from https:// chronicle.com/article/ Scholars-Sound-the-Alert-From/139103/ 
Rivard, R. (2013, February 21). Twice as many MOOCs. Inside Higher Ed. Retrieved from http:// www.insidehighered.com/news/2013/02/21/ coursera-and-edxadd-universities-and-hope-expand-global-reach

Rivard, R. (2013, February 27). Rate my MOOCs. Inside Higher Ed. Retrieved from http:// www.insidehighered.com/news/2013/02/27/ users-grade-free-onlinecourses

Rivard, R. (2013, February 28). The MOOC-averse technology U. Inside Higher Ed. Retrieved from http:/ / www.insidehighered.com/news/ 2013/02/28/carnegiemellons-online-efforts-include-spinoffs-and-subsidiaries-not-moocs

Rivard, R. (2013, March 8). Measuring the MOOC dropout rate. Inside Higher Ed. Retrieved from http:// www.insidehighered.com/news/2013/03/08/ researchers-explore-whotaking-moocs-and-why-so-many-drop-out

Rivard, R. (2013, March 19). Who owns a MOOC. Inside Higher Ed. Retrieved from http:// www.insidehighered.com/news/2013/03/ 19/u-california-faculty-unionsays-moocs-undermine-professors-intellectual-property

Rivard, R. (2013, March 22). Coursera commits to admitting only elite universities. Inside Higher Ed. Retrieved from http:// www.insidehighered.com/ news/2013/03/22/ coursera-commitsadmitting-only-elite-universities

Rubin, B. (2013, J anuary 28). Online courses: Possibilities and pitfalls. [Letter to the editor.] The New York Times. Retrieved from http:// www.nytimes.com/2013/01/29/opinion/online-courses-possibilitiesand-pitfalls.html

Schmidt, M. (2013). MOOCs: Massive opportunity or mucky mess? ASQ Higher Education Brief, 6(2). Retrieved from http:// asq.org/ edu/2013/03/innovation/ moocs-massive-opportunity-ormucky-mess.pdf?WT.dcsvid=ODk0Mzg1MTAyNAS2\&WT.mc id=EM119905

The Chronicle of Higher Education. (2013, J une 10). What you need to know about MOOCs. Retrieved from http:// chronicle.com/ article/ What-You-Need-toKnow-About/133475/

Vaidhyanathan, S. (2012, J uly 6). What's the matter with MOOCs? The Chronicle of Higher Education. Retrieved from http:// chronicle.com/blogs/innovations/ whats-the-matter-with-moocs/ 33289 
Vaidhyanathan, S. (2012, J uly 18). Going public the UVa way. The Chronicle of Higher Education. Retrieved from http:// chronicle.com/blogs/innovations/goingpublic-the-uva-way/ 33623

Young, J . R. (2012, J uly 19). Inside the Coursera contract: How an upstart company might profit from free courses. The Chronicle of Higher Education. Retrieved from http:/ / chronicle.com/article/ How-an-Upstart-Company-Might/ 133065/

Young, J . R. (2012, September 25). When professors print their own diplomas, who needs universities? The Chronicle of Higher Education. Retrieved from http://chronicle.com/article/When-Professors-Print-Their/ 1185

Young, J . R. (2012, November 13). American Council on Education may recommend some Coursera offerings for college credit. The Chronicle of Higher Education. Retrieved from http:// chronicle.com/article/American-Council-onEducation/135750/

Young, J . R. (2013, April 3). Stanford U. and edX will jointly build open-source software to deliver MOOCs. The Chronicle of Higher Education. Retrieved from http://chronicle.com/blogs/ wiredcampus/stanford-u-and-edx-will-jointlybuild-open-source-software-to-deliver-moocs/43301

Wallis, D. (2013, March 18). Colleges assess cost of free online-only courses. The New York Times. Retrieved from http:// www.nytimes.com/2013/03/19/ education/ colleges-assess-cost-of-freeonline-only-courses.html?ref=nationalspecial $2 \& \_r=0$

\section{Athabasca University $\mathbf{a}$}

(2) $\stackrel{0}{\mathrm{IV}}$ 